\title{
ELASTIC BEHAVIOUR OF MAGNESIA-CHROME REFRACTORIES AT ELEVATED TEMPERATURES
}

\author{
ELASTIČNO VEDENJE OGNJEVZDRŽNIH GRADIV \\ MAGNEZIJA-KROM PRI POVIŠANIH TEMPERATURAH
}

\author{
Ilona Jastrzębska, Jacek Szczerba, Jakub Szlęzak, Edyta Śnieżek, \\ Zbigniew Pędzich \\ AGH University of Science and Technology, al. A. Mickiewicza 30, 30-059 Kraków, Poland \\ ijastrz@agh.edu.pl \\ Prejem rokopisa - received: 2014-08-08; sprejem za objavo - accepted for publication: 2015-01-14
}

doi: $10.17222 /$ mit.2014.186

\begin{abstract}
An investigation of the high-temperature elastic behaviour of four varieties of magnesia-chrome products was conducted in the present work. The starting materials were characterized with XRF, XRD and SEM/EDS analyses. The measurements of the dynamic Young's modulus were performed in a temperature range of $20-1300{ }^{\circ} \mathrm{C}$, using the acoustic method. Moreover, the dynamic Young's moduli, shear moduli and Poisson's ratios were established at ambient temperature for the original and after-heating samples. The obtained results showed similar characteristics, but the elastic behaviours of all the refractory test materials were distinguishable. The curve of the Young's modulus changed as a function of temperature, exhibiting a close-to-hysteresis character, with a decreasing area between the lower and upper curve as $\operatorname{the~} \mathrm{Cr}_{2} \mathrm{O}_{3}$ content increased in the material. The Young's modulus and the shear modulus at ambient temperature were lower for the after-heating samples when compared to the original ones.

Keywords: Young's modulus, elastic properties, refractories, shear modulus, Poisson's ratio
\end{abstract}

V tem delu je opisana preiskava visokotemperaturnih elastičnih lastnosti magnezija-kromovih proizvodov. Začetni materiali so bili ocenjeni $\mathrm{z}$ analizo XRF, XRD in SEM/EDS. V območju temperatur $20-1300{ }^{\circ} \mathrm{C}$ so bile izvršene meritve dinamičnega Young-ovega modula z akustično metodo. Nadalje so bili določeni dinamični Young-ov modul, strižni modul in Poisson-ovo število pri sobni temperaturi originalnih in toplotno obdelanih vzorcih. Dobljeni rezultati so pokazali podoben karakter, vendar pa se je elastično vedenje vseh preizkušanih ognjevzdržnih materialov razlikovalo. Krivulja Young-ovega modula se spreminja v odvisnosti od temperature, ima ozek histerezni karakter z zmanjšanjem področja med spodnjo in zgornjo krivuljo, ko vsebnost $\mathrm{Cr}_{2} \mathrm{O}_{3} \mathrm{v}$ materialu narašča. Young-ov strižni modul je bil pri sobni temperaturi nižji pri žarjenih vzorcih v primerjavi z originalnimi.

Ključne besede: Young-ov modul, elastične lastnosti, ognjevzdržna gradiva, strižni modul, Poisson-ovo število

\section{INTRODUCTION}

The rapidly growing interest in the high-temperature elastic properties arises from their great usefulness in the area of designing of refractory materials and predicting their lifetime. Notwithstanding, the literature about this issue is still scarce. The Young's modulus $(E)$, as one of the most relevant elastic-material constants, is directly associated with the thermal-shock resistance, which is a very important property during the first heating stage of the refractory furnace lining, or when it is subjected to permanent thermal stresses as in steel ladles, tundishes or oxygen convertors used for pig-iron production in the industrial metallurgy.

The commonly applied method for determining the Young's modulus includes the measurements of the speed of the ultrasonic-wave propagation in a material. This method allows us to measure the property at ambient temperatures only. However, in real working conditions the knowledge of the properties at elevated temperatures is more valuable.

The magnesia-chrome refractories $\left(\mathrm{MgO}-\mathrm{Cr}_{2} \mathrm{O}_{3}\right)$ are specific materials with multi-component complex micro- structures composed of magnesia, introduced as a clinker, and a solid solution of spinels like chromite, magnesiochromite, magnesioferrite, a regular spinel or hercynite, introduced with a chromite-ore concentrate. Both components may also be introduced with a magnesia-chromite co-clinker, which is a burning product of these two components. This group of refractory materials is no longer developed to be used for rotary-kiln linings because of the toxicity of hexavalent chromium compounds, but it is still very important in the metallurgy of iron, lead or copper. ${ }^{1,2}$

Therefore, the purpose of this work is to assess the elastic behaviour of a few magnesia-chrome refractory materials with slightly different chemical compositions, both at elevated and ambient temperatures.

\section{EXPERIMENTAL WORK}

The four varieties of magnesia-chrome (MCr) refractory products designated in order of increasing content of $\mathrm{Cr}_{2} \mathrm{O}_{3}$ as $\mathrm{MCr} 1, \mathrm{MCr} 2, \mathrm{MCr} 3$ and $\mathrm{MCr} 4$, industrially shaped and fired, were investigated. The test materials 
were produced with the use of magnesia-chrome co-clinker, fused-magnesia clinker and a chrome-ore concentrate. As a result of different proportions between the used raw materials, the products contained slightly different amounts of $\mathrm{Cr}_{2} \mathrm{O}_{3}$ in the range of 18.0-21.8\% and $\mathrm{MgO}$ in the range of $61.3-68.4 \%$. The $\mathrm{CaO} / \mathrm{SiO}_{2}$ ratio for all of the materials was below 1 .

Detailed chemical compositions determined with the XRF method, together with the basic properties of the examined products, are presented in Table $\mathbf{1}$. It can be observed from this table that the test samples exhibit slightly different open porosities which increase with the decreasing ferric-oxide content. The average thermalshock resistance (TSR) of MCr1 is the same as for MCr4 (10 cycles) while for $\mathrm{MCr} 2$ it takes on the same value as for $\mathrm{MCr} 3$ (6 cycles).

Table 1: Basic properties of the examined materials

Tabela 1: Osnovne lastnosti preiskovanih materialov

\begin{tabular}{|c|c|c|c|c|}
\hline \multirow[t]{2}{*}{ Property } & \multicolumn{4}{|c|}{ Material designation } \\
\hline & MCr1 & $\mathrm{MCr} 2$ & MCr3 & $\mathrm{MCr} 4$ \\
\hline Open porosity, \% & 14.0 & 13.8 & 12.1 & 15.6 \\
\hline Apparent density, $\mathrm{g} / \mathrm{cm}^{3}$ & 3.11 & 3.17 & 3.23 & 3.07 \\
\hline Compressive strength, $\mathrm{MPa}$ & 62.2 & 94.8 & 100.7 & 48.3 \\
\hline $\begin{array}{l}\text { Bending strength at } 20^{\circ} \mathrm{C} \text {, } \\
\mathrm{MPa}\end{array}$ & 6.8 & 9.7 & 8.6 & 7.2 \\
\hline $\begin{array}{l}\text { Bending strength at } \\
1450^{\circ} \mathrm{C}, \mathrm{MPa}\end{array}$ & 2.5 & 4.9 & 4.7 & 3.3 \\
\hline $\begin{array}{l}\text { Average thermal-shock } \\
\text { resistance }(T S R) \text {, cycles at } \\
950^{\circ} \mathrm{C} \text {, water }\end{array}$ & 10 & 6 & 6 & 10 \\
\hline Oxide & \multicolumn{4}{|c|}{ Oxide content, $w / \%$} \\
\hline $\mathrm{MgO}$ & 68.4 & 66.4 & 61.3 & 64.2 \\
\hline $\mathrm{Cr}_{2} \mathrm{O}_{3}$ & 18.0 & 18.45 & 19.9 & 21.8 \\
\hline $\mathrm{Fe}_{2} \mathrm{O}_{3}$ & 7.0 & 8.1 & 10.2 & 6.7 \\
\hline $\mathrm{Al}_{2} \mathrm{O}_{3}$ & 4.0 & 4.4 & 5.4 & 4.2 \\
\hline $\mathrm{CaO}$ & 0.88 & 0.82 & 1.07 & 0.85 \\
\hline $\mathrm{SiO}_{2}$ & 1.28 & 1.34 & 1.23 & 1.79 \\
\hline
\end{tabular}

The XRD analysis of the investigated products was performed at room temperature, using a PANanalytical X'Pert Pro MPD X-ray diffractometer with Bragg-Brentano geometry, and $\mathrm{Cu}-K \alpha$ radiation $(\lambda=0.154056 \mathrm{~nm})$, in a range of $10^{\circ} \leq 2 \theta<90^{\circ}$. The obtained XRD patterns, illustrated in Figure 1, show two main compo-

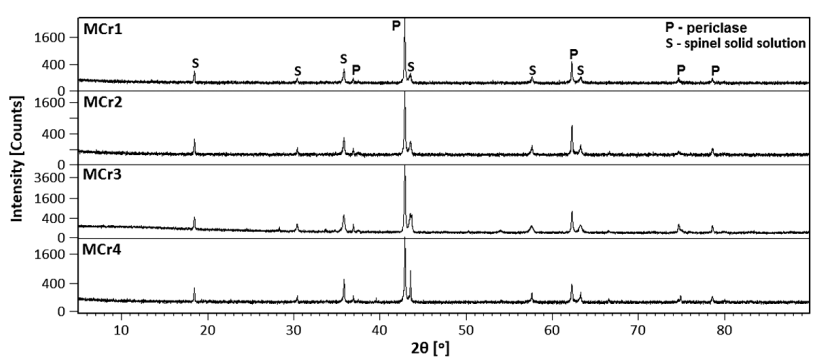

Figure 1: XRD patterns of test materials $\mathrm{MCr} 1, \mathrm{MCr} 2, \mathrm{MCr} 3$ and $\mathrm{MCr} 4$

Slika 1: XRD-posnetki preizkusnih materialov $\mathrm{MCr} 1, \mathrm{MCr} 2, \mathrm{MCr} 3$ in $\mathrm{MCr} 4$ nents which correspond to periclase (marked as $\mathrm{P}$ on the diffractogram) and a complex solid solution of spinels with an approximate chemical formula that can be expressed as $(\mathrm{Mg}, \mathrm{Fe})(\mathrm{Cr}, \mathrm{Al}, \mathrm{Fe})_{2} \mathrm{O}_{4}$ (marked as $\mathrm{S}$ on the diffractogram). The main difference between the registered patterns is associated with different intensities of the reflexes of the spinel solid solution, which generally increase with an increased content of $\mathrm{Cr}_{2} \mathrm{O}_{3}$ in the material.

The microstructures of the starting materials were observed under an ultra-high-definition scanning electron microscope, NovaNanosem200 equipped with an energy dispersive spectrometer, EDS. The samples for the BSE-SEM/EDS analysis were prepared as resin-embedded cross-sections using the traditional ceramographic method. The exemplary microstructures of the magnesia-chrome products are presented in Figures $\mathbf{2}$ to $\mathbf{5}$. As it can be observed from the figures, the test products do not differ significantly in their microstructures.

Periclase grains (visible in the SEM images as dark-grey areas) contain inclusions of the $(\mathrm{Mg}, \mathrm{Mn}$, $\mathrm{Fe})(\mathrm{Al}, \mathrm{Cr}, \mathrm{Fe})_{2} \mathrm{O}_{4}$ solid solution (Figures $\mathbf{2}$ and $\mathbf{3}$ - point 1, Figure 5 - point 4). They represent magnesia co-clinker used as the raw material. Pure grains of magnesia clinker are also present in the material (Figure 2 -
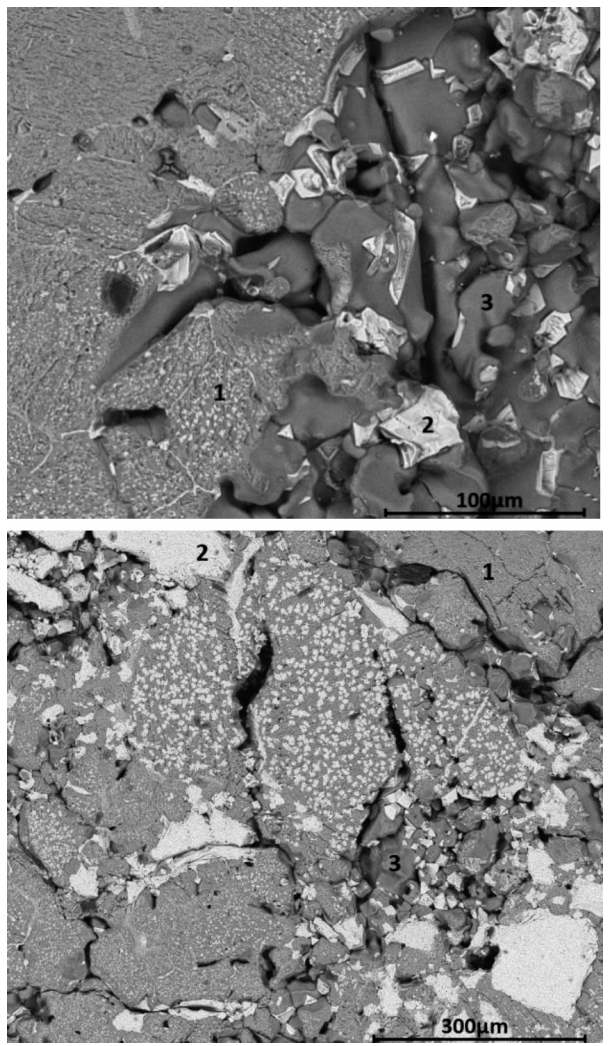

Figure 2: SEM images of MCr1 product: $1-\mathrm{MgO}$ with inclusions of solid solution $(\mathrm{Mg}, \mathrm{Fe})(\mathrm{Al}, \mathrm{Cr}, \mathrm{Fe})_{2} \mathrm{O}_{4}, 2$ - solid solution $(\mathrm{Mg}, \mathrm{Mn}$, $\mathrm{Fe})(\mathrm{Al}, \mathrm{Cr}, \mathrm{Fe})_{2} \mathrm{O}_{4}, 3-\mathrm{MgO}$

Slika 2: SEM-posnetka proizvoda MCr1: 1 - MgO z vključki trdne raztopine $(\mathrm{Mg}, \mathrm{Fe})(\mathrm{Al}, \mathrm{Cr}, \mathrm{Fe})_{2} \mathrm{O}_{4}, 2$ - trdna raztopina $(\mathrm{Mg}, \mathrm{Mn}, \mathrm{Fe})$ $(\mathrm{Al}, \mathrm{Cr}, \mathrm{Fe})_{2} \mathrm{O}_{4}, 3-\mathrm{MgO}$ 

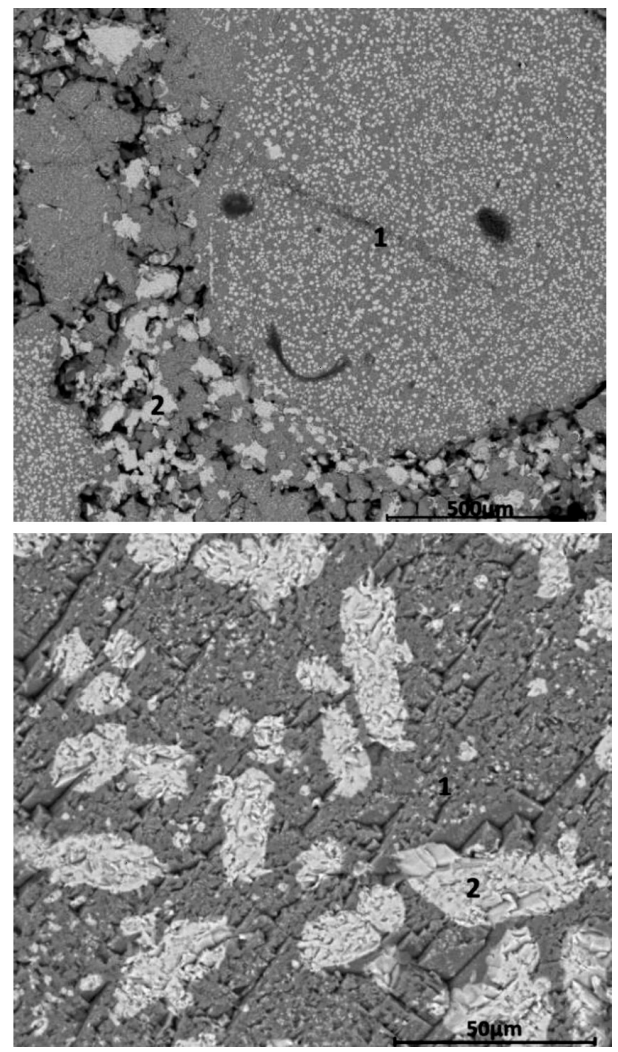

Figure 3: SEM images of $\mathrm{MCr} 2$ product: $1-\mathrm{MgO}$ with inclusions of solid solution $(\mathrm{Mg}, \mathrm{Fe})(\mathrm{Al}, \mathrm{Cr}, \mathrm{Fe})_{2} \mathrm{O}_{4}, 2$ - solid solution $(\mathrm{Mg}, \mathrm{Mn})$ $(\mathrm{Al}, \mathrm{Cr})_{2} \mathrm{O}_{4}$

Slika 3: SEM-posnetka produkta $\mathrm{MCr} 2: 1-\mathrm{MgO}$ z vključki trdne raztopine $(\mathrm{Mg}, \mathrm{Fe})(\mathrm{Al}, \mathrm{Cr}, \mathrm{Fe})_{2} \mathrm{O}_{4}, 2$ - trdna raztopina $(\mathrm{Mg}, \mathrm{Mn})(\mathrm{Al}$, $\mathrm{Cr})_{2} \mathrm{O}_{4}$
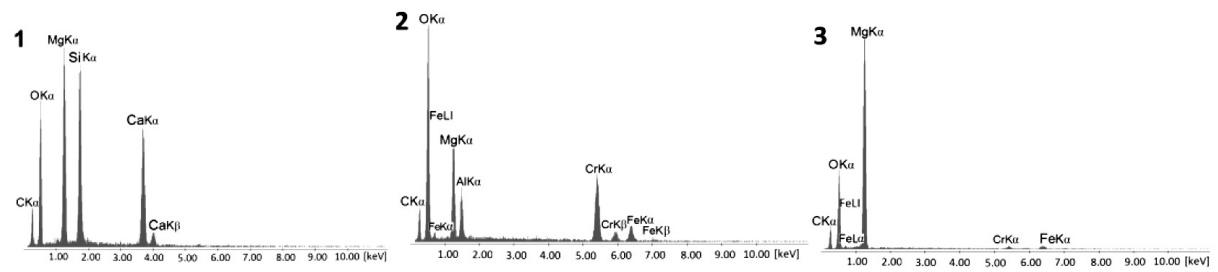
inclusions of solid solution $(\mathrm{Mg}, \mathrm{Mn}, \mathrm{Fe})(\mathrm{Al}, \mathrm{Cr}, \mathrm{Fe})_{2} \mathrm{O}_{4}$ vključkom trdne raztopine $(\mathrm{Mg}, \mathrm{Mn}, \mathrm{Fe})(\mathrm{Al}, \mathrm{Cr}, \mathrm{Fe})_{2} \mathrm{O}_{4}$
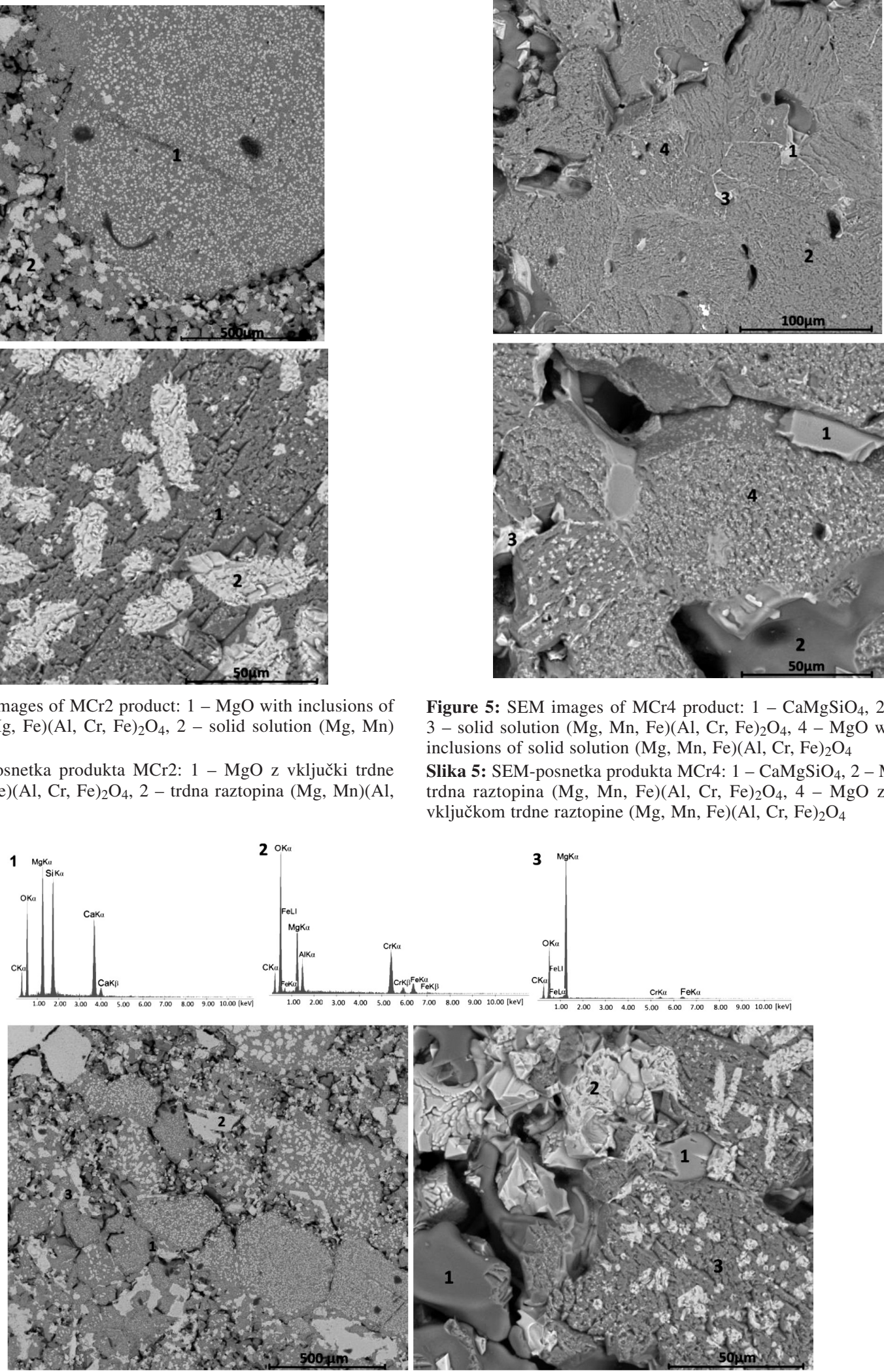

Figure 5: $\mathrm{SEM}$ images of $\mathrm{MCr} 4$ product: $1-\mathrm{CaMgSiO}_{4}, 2-\mathrm{MgO}$, 3 - solid solution $(\mathrm{Mg}, \mathrm{Mn}, \mathrm{Fe})(\mathrm{Al}, \mathrm{Cr}, \mathrm{Fe})_{2} \mathrm{O}_{4}, 4-\mathrm{MgO}$ with large

Slika 5: SEM-posnetka produkta MCr4: $1-\mathrm{CaMgSiO}_{4}, 2-\mathrm{MgO}, 3-$ trdna raztopina $(\mathrm{Mg}, \mathrm{Mn}, \mathrm{Fe})(\mathrm{Al}, \mathrm{Cr}, \mathrm{Fe})_{2} \mathrm{O}_{4}, 4-\mathrm{MgO}$ z velikim

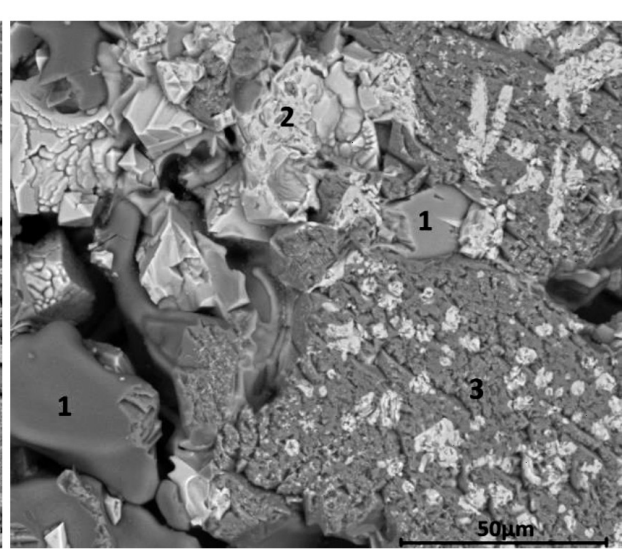

Figure 4: $\mathrm{SEM}$ images of the $\mathrm{MCr} 3$ product along with the EDS analysis for points 1,2 and $3: 1-\mathrm{CaMgSiO}_{4}, 2-(\mathrm{Mg}, \mathrm{Fe})(\mathrm{Al}, \mathrm{Cr}, \mathrm{Fe})_{2} \mathrm{O}_{4}, 3-$ $\mathrm{MgO}$ enriched with iron and chromium

Slika 4: SEM-posnetka produkta MCr3 z EDS-analizo v točkah 1, 2 in 3: $1-\mathrm{CaMgSiO}_{4}, 2-(\mathrm{Mg}, \mathrm{Fe})(\mathrm{Al}, \mathrm{Cr}, \mathrm{Fe})_{2} \mathrm{O}_{4}, 3-\mathrm{MgO}$, obogaten z železom in kromom 


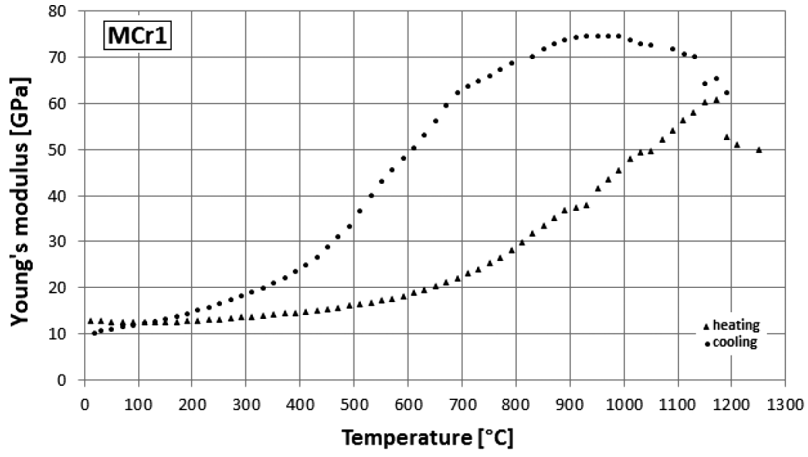

Figure 6: Young's modulus $E$ versus the temperature during heating (triangles) and cooling (dots) for the material MCr1

Slika 6: Young-ov modul $E$ v odvisnosti od temperature med ogrevanjem (trikotniki) in ohlajanjem (točke) za material MCr1

point 3, Figure 5 - point 2). The lightest areas comprise a complex solid solution containing iron, $(\mathrm{Mg}, \mathrm{Mn}$, $\left.\mathrm{Fe}^{2+}\right)\left(\mathrm{Al}, \mathrm{Cr}, \mathrm{Fe}^{3+}\right)_{2} \mathrm{O}_{4}$ (Figures 2 and $\mathbf{4}$ - point 2, Figure 5 - point 3 ), or without iron, $(\mathrm{Mg}, \mathrm{Mn})(\mathrm{Al}, \mathrm{Cr})_{2} \mathrm{O}_{4}$ (Figure 3 - point 2). Calcium magnesium silicate (monticellite) was also detected in the microstructures of the $\mathrm{MCr} 3$ and $\mathrm{MCr} 4$ products, visible as the light-grey areas located between the magnesia-chrome co-clinker grains (Figures $\mathbf{4}$ and $\mathbf{5}$ - point $\mathbf{1}$ ).

The changes in the Young's modulus, depending on the temperature, were measured in the heating conditions at the maximum temperature of $1300{ }^{\circ} \mathrm{C}$ using a resonant-frequency and damping analyser RFDA HT-1600. The test samples, of rectangular cross-sections, had dimensions of $100 \mathrm{~mm} \times 40 \mathrm{~mm} \times 20 \mathrm{~mm}$. The temperature increment during the heating was set to $2^{\circ} \mathrm{C} / \mathrm{min}$ while for the cooling it was $5{ }^{\circ} \mathrm{C} / \mathrm{min}$. The holding time at the maximum temperature was $20 \mathrm{~min}$.

The ambient-temperature measurements of the dynamic Young's modulus, shear modulus $(G)$ and Poisson's ratio $(v)$ were carried out on both the original samples and on the samples after the $E$-modulus measurements at elevated temperatures. Two samples, with rectangular cross-sections and the same dimensions, $100 \mathrm{~mm} \times 40$ $\mathrm{mm} \times 20 \mathrm{~mm}$, of each type of the material were sub-

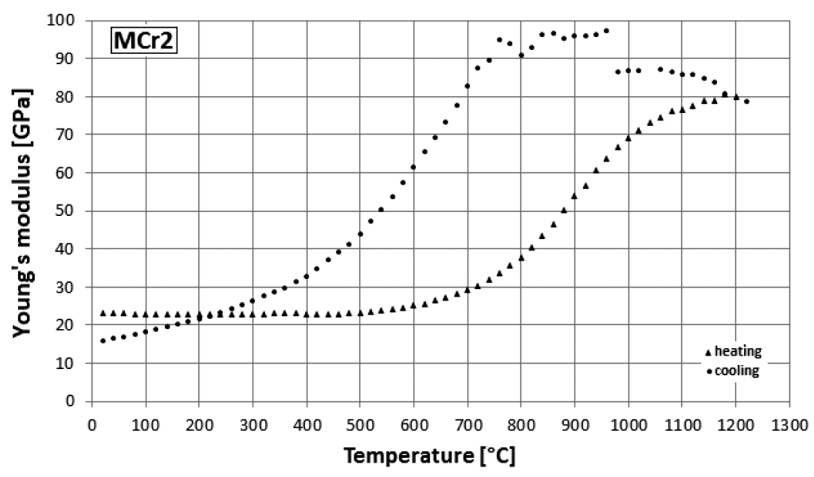

Figure 7: Young's modulus $E$ versus the temperature during heating (triangles) and cooling (dots) for the material MCr2

Slika 7: Young-ov modul $E$ v odvisnosti od temperature med ogrevanjem (trikotniki) in ohlajanjem (točke) za material MCr2

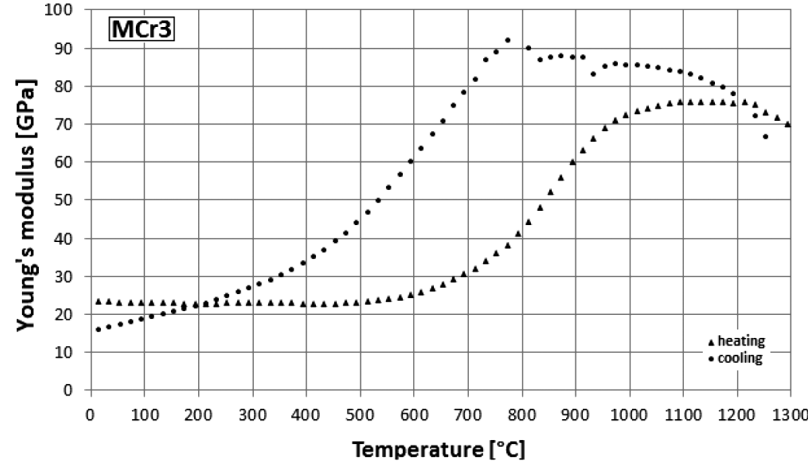

Figure 8: Young's modulus $E$ versus the temperature during heating (triangles) and cooling (dots) for the material $\mathrm{MCr} 3$

Slika 8: Young-ov modul $E \mathrm{v}$ odvisnosti od temperature med ogrevanjem (trikotniki) in ohlajanjem (točke) za material MCr3

jected to an investigation. Therefore, the average modulus value for each sample was accounted for by the average value of the two measurements. The test was conducted with a RFTA Professional apparatus, in the flexural and torsion modes of vibrations, in accordance with the ASTM E 1876-09 standard. $^{3}$

\section{RESULTS}

Figures 6 to 9 depict the dependence between the Young's modulus $(E)$ and the temperature during the process of heating and cooling the samples. At the first sight, the sequences of the measured points for all of the examined materials look similar, exhibiting a "dolphinlike" shape. These measured-point sequences arrangement also resembles a hysteresis function, with a decreasing area between the lower and upper points as the $\mathrm{Cr}_{2} \mathrm{O}_{3}$ content increases in the material.

The common feature of all the investigated products is an evident increase of the heating slope which begins at about $600{ }^{\circ} \mathrm{C}$. The $\mathrm{MCr} 1$ product, characterized by the lowest $\mathrm{Cr}_{2} \mathrm{O}_{3}$ content and a high open porosity, exhibited the widest hysteresis and the lowest value of the initial Young's modulus read off from the $E(T)$ dependence as 12.7 GPa (Figure 6). During the heating of this sample,

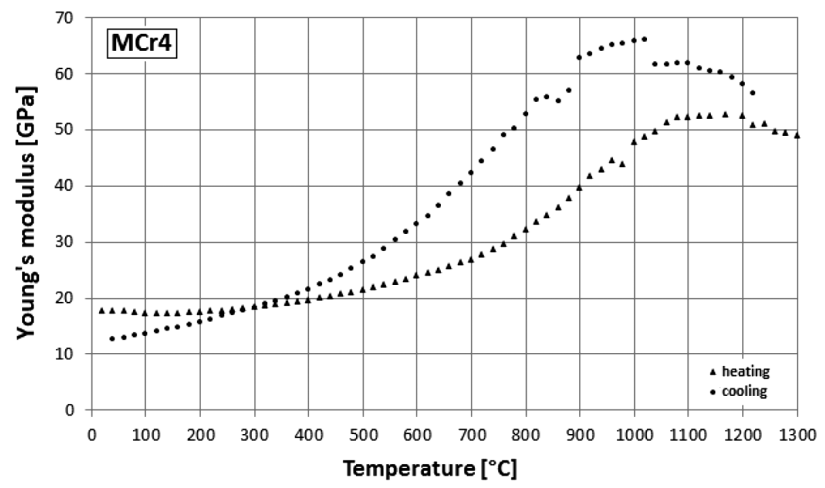

Figure 9: Young's modulus $E$ versus the temperature during heating (triangles) and cooling (dots) for the material $\mathrm{MCr} 4$

Slika 9: Young-ov modul $E \mathrm{v}$ odvisnosti od temperature med ogrevanjem (trikotniki) in ohlajanjem (točke) za material MCr4 
the maximum $E$ value of $60.7 \mathrm{GPa}$ was achieved at 1172 ${ }^{\circ} \mathrm{C}$. Then, the elastic modulus decreased and reached the minimum value of $50 \mathrm{GPa}$ at $1252^{\circ} \mathrm{C}$. Such an increase followed by a decrease in the Young's modulus during the heating cycles was observed for all the investigated samples. The maximum $E$ value of $80.7 \mathrm{GPa}$, during the heating cycle, was registered for the $\mathrm{MCr} 2$ material at $1181{ }^{\circ} \mathrm{C}$ (Figure 7).

The cooling-cycle point sequence, for all the examined materials, showed an evident increase in the elastic modulus and a following gradual decrease, finally reaching an $E$ value that was lower than the starting one, registered at the beginning of the test. In spite of the fact that the MCr1 and $\mathrm{MCr} 4$ products differ mostly in the area between the heating and cooling slopes, their values of the initial and final $E$ moduli are the closest and so are their elastic moduli at the maximum temperature. On the other hand, the MCr2 and $\mathrm{MCr} 3$ materials, exhibiting similar sequences of the measured points and the areas between them, achieve similar $E$-modulus values both at the ambient and maximum temperatures of the test. It is worth to note that these two "pairs" of the materials exhibit the same thermal-shock resistance that can be observed from Table 1 (TSR: MCr2 $=\mathrm{MCr} 3=6$ and MCr1 = MCr4 = 10).

Table 2: Results of Young's modulus $(E)$, shear modulus $(G)$ and Poisson's $(v)$ ratio measured at ambient temperature

Tabela 2: Young-ov modul $(E)$, strižni modul $(G)$ in Poisson-ovo število $(v)$, izmerjeno pri sobni temperaturi

\begin{tabular}{|c|c|c|c|c|c|}
\hline $\begin{array}{c}\text { Sample } \\
\text { designation }\end{array}$ & $E / \mathrm{GPa}$ & $\begin{array}{c}E \text { decrease } \\
\text { after heat- } \\
\text { ing, } \%\end{array}$ & $G / \mathrm{GPa}$ & $\begin{array}{c}G \text { decrease } \\
\text { after heat- } \\
\text { ing, } \%\end{array}$ & $v$ \\
\hline $\mathrm{MCr}_{\mathrm{o}}$ & $\begin{array}{c}13.80 \pm \\
0.14\end{array}$ & \multirow{2}{*}{16.1} & $\begin{array}{c}7.28 \pm \\
0.07\end{array}$ & \multirow{2}{*}{17.4} & -0.052 \\
\hline $\mathrm{MCr}_{\mathrm{h}}$ & $\begin{array}{c}11.58 \pm \\
0.12\end{array}$ & & $\begin{array}{c}6.01 \pm \\
0.06\end{array}$ & & -0.038 \\
\hline $\operatorname{MCr} 2_{0}$ & $\begin{array}{c}21.51 \pm \\
0.22\end{array}$ & \multirow{2}{*}{20.9} & $\begin{array}{c}10.43 \pm \\
0.10\end{array}$ & \multirow{2}{*}{18.5} & 0.031 \\
\hline $\mathrm{MCr} 2_{\mathrm{h}}$ & $\begin{array}{c}17.02 \pm \\
0.17\end{array}$ & & $\begin{array}{c}8.50 \pm \\
0.09\end{array}$ & & 0.001 \\
\hline $\mathrm{MCr}_{\mathrm{o}}$ & $\begin{array}{c}24.41 \pm \\
0.24\end{array}$ & \multirow{2}{*}{22.4} & $\begin{array}{c}12.29 \pm \\
0.12\end{array}$ & \multirow{2}{*}{22.8} & -0.007 \\
\hline $\mathrm{MCr}_{\mathrm{h}}$ & $\begin{array}{c}18.93 \pm \\
0.19\end{array}$ & & $\begin{array}{c}9.49 \pm \\
0.09\end{array}$ & & -0.003 \\
\hline $\mathrm{MCr}_{\mathrm{o}}$ & $\begin{array}{c}17.62 \pm \\
0.18\end{array}$ & \multirow{2}{*}{20.8} & $\begin{array}{c}8.08 \pm \\
0.08\end{array}$ & \multirow{2}{*}{20.4} & 0.091 \\
\hline $\mathrm{MCr}_{\mathrm{h}}$ & $\begin{array}{c}13.96 \pm \\
0.14\end{array}$ & & $\begin{array}{c}6.43 \pm \\
0.06\end{array}$ & & 0.086 \\
\hline
\end{tabular}

Designation indexes: o - original sample, $\mathrm{h}$ - after-heating sample

Table 2 presents the results of the Young's moduli and shear moduli determined with the standard deviation as well as Poisson's ratios calculated with the equations given in ASTM E 1876-09 for the samples with a rectangular geometry. It can be observed that in each case the Young's and shear moduli of the after-heating samples are lower in comparison to the original ones. Here, the "pairs" of the test materials with similar $E$ and $G$ moduli can also be distinguished. The moduli for
MCr1 are the most similar to the ones for $\mathrm{MCr} 4 . \mathrm{A}$ similar situation occurs when comparing the $\mathrm{MCr} 2$ and MCr3 materials.

It is worth emphasizing that the drops in the $E$ values, for all the materials, entail a decrease in the shear moduli. The highest values of the $E$ and $G$ moduli for both the original and after-heating samples were obtained for the $\mathrm{MCr} 3$ sample, while the lowest values were registered for $\mathrm{MCr} 1$. The results obtained for Poisson's ratio $v$ showed that in each case its value was lower for the original sample when compared to the after-heating one. Moreover, for the MCr1 and MCr3 samples the $v$ ratios even reached negative values, whereas for the rest of the samples they were positive.

\section{DISCUSSION}

Firstly, it should be emphasized that magnesiachrome materials are highly complex systems because they are composed of magnesia and a few spinel compounds that often form solid solutions with different proportions, making them even more complex. Among these spinels the following can be found: chromite $\mathrm{FeCr}_{2} \mathrm{O}_{4}$, magnesiochromite $\mathrm{MgCr}_{2} \mathrm{O}_{4}$, regular spinel $\mathrm{MgAl}_{2} \mathrm{O}_{4}$, magnesioferrite $\mathrm{MgFe}_{2} \mathrm{O}_{4}$, galaxite $\mathrm{MnAl}_{2} \mathrm{O}_{4}$ and hercynite $\mathrm{FeAl}_{2} \mathrm{O}_{4}$.

The present mixture of the mentioned spinels was found with the SEM observations and was also confirmed by the XRD analysis. It is worth noting that there is a good repeatability of the achieved results with regard to the curve shape created (Figures 6 to 9) by the obtained point sequences, despite the fact that these were industrial samples, in which an unavoidable spread of commercial properties may occur.

All the measured point sequences resemble a hysteresis function, which arises from the thermal history of a sample. The initial increasing character of an $E(T)$ curve is associated with a densification of the microstructure due to a partial oxidation of $\mathrm{Fe}^{2+}$ into $\mathrm{Fe}^{3+}$, which starts above $300{ }^{\circ} \mathrm{C},{ }^{1}$ leading to a modification of the existing spinel solid solution due to an incorporation of oxygen into the structure, or due to a grain reorganization as a result of the stress during the test and the increased temperature.

Above the temperature of $500{ }^{\circ} \mathrm{C}$ a more intense growth of the heating slope probably originates from an "order-disorder" phase transformation, occurring in the solid mixtures with a spinel structure. This phenomenon derives from the propensity of the ions to change their local positions in the structure. The ions in the $2+$ oxidation states, which are regularly located in the tetrahedral $(\mathrm{T})$ sites, pass to the octahedral $(\mathrm{M})$ ones that are normally occupied by the $3+$ ions, and vice versa. ${ }^{4}$ It is called a transition into an "inversion structure", which is followed by the changes in the structural-parameter values, like the oxygen parameter or the cation-anion distance in the $\mathrm{T}$ and $\mathrm{M}$ sites. 
The literature quotes that cation disordering considerably affects the elasticity, ${ }^{5}$ the compressibility and the thermal-expansion coefficient. ${ }^{6-8}$ The beginning of an inversion transformation corresponds to different temperatures, depending on the type of spinel. After reaching the maximum value of the Young's modulus, the curve (the author has in mind a continuous sequence of measured points) starts to drop until reaching the maximum temperature of the test, which needs a further investigation. The cooling cycle after the maximum temperature starts with an increase in the $E$ modulus reaching the maximum value for all the test materials. This behaviour exhibits the "strengthening" of the material in the average temperature range of $800-1000{ }^{\circ} \mathrm{C}$, which may be the effect of the recrystallization process and filling the voids.

In the case of the $\mathrm{MCr} 1$ material the $E$-modulus change exhibits an almost continuous character during the cooling process, whereas in the cases of the other samples this dependence is discontinuous, requiring a further investigation. The following gradual drop in the $E(T)$ dependence is probably related with the stress relaxation due to a microcrack formation or, as previously reported by Podwórny et al. ${ }^{9}$, a channel-like pore formation, which triggers the loosening of the microstructure. Even though the test materials are not considerably different in their chemical and phase compositions, they exhibit distinguishable behaviours of the elastic-modulus change. Therefore, the $E(T)$ dependence may represent a "finger print" of the material. It proves that this method can be highly helpful for assessing the high-temperature behaviour of refractory materials.

The obtained lower values of the $E$ moduli at ambient temperature for all the after-heating MCr samples (Table 2) are the results of microcracks or other defects formed during the heating of the materials. The decreased Young's moduli $(E)$ are accompanied by simultaneous decreases in the shear moduli $(G)$. These two moduli, together with Poisson's ratio $(v)$, are expressed with a well-known equation, $v=(E / 2 G)-1$. It can be observed that the MCr1 and $\mathrm{MCr} 3$ products exhibit negative values of Poisson's ratio for both the original and after-heating samples. Such a behaviour of a material was also previously reported. ${ }^{9,10}$ The negative values of Poisson's ratio show that the material unfolds when it is subjected to stretching ${ }^{11}$ and the negative $v$ obtained in this research can be ascribed to the rearrangement and rotation of the microstructural components such as large grains, used for the production of the material, or the pores that are always present in the microstructures of refractory materials.

Notwithstanding, it is difficult to relate these ratios with the elastic behaviour, chemical composition and type of the material investigated in this study. The calculated percentage changes in the $E$ and $G$ values after the heating (during the test at elevated temperatures) (Table 2) show that the tensile, compressive and shear stresses have almost equally destructive effects on materials $\mathrm{MCr} 3$ and $\mathrm{MCr} 4$. On the other hand, according to the obtained results, the properties of the $\mathrm{MCr} 1$ material are more influenced by the shear stress, while for the $\mathrm{MCr} 2$ material the tensile and compressive stresses play prevailing roles.

\section{CONCLUSIONS}

1. The high-temperature investigation of the elastic properties of magnesia-chrome refractories showed hysteresis-like behaviours. The hysteresis range was the widest for the $\mathrm{MCr} 1$ product with the lowest amount of $\mathrm{Cr}_{2} \mathrm{O}_{3}$ and the narrowest for the $\mathrm{MCr} 4$ product with the largest amount of $\mathrm{Cr}_{2} \mathrm{O}_{3}$.

2. Different $E$ moduli obtained at elevated temperatures for the magnesia-chrome products prove that the used method may be helpful for predicting the high-temperature behaviour and lifetime of this kind of widely applied refractory materials.

3. The dynamic Young's moduli and shear moduli, measured at ambient temperature, were found to be lower for the after-heating samples when compared to the original ones, which was the result of the defects formed during the heating process.

\section{Acknowledgements}

This work was supported by grant no. UDA-POIG. 01.04.00-18-028/11-00.

\section{REFERENCES}

${ }^{1}$ F. Nadachowski, Outline of refractory materials technology, Silesia Technical Publishing, Katowice 1995 (in Polish)

${ }^{2}$ M. Szymaszek, J. Szczerba, W. Zelik, Directions in development of refractories for the cement and lime industry, Ceramic Materials, 63 (2011) 3, 608-613 (in Polish)

${ }^{3}$ ASTM E 1876-09, 2009, doi:10.1520/E1876-09

${ }^{4}$ K. E. Sickafus, J. M. Wills, N. W. Grimes, Spinel compounds: structure and property relations, Journal of American Ceramic Society, 82 (1999) 12, 3279-3292, doi:10.1111/j.1151-2916.1999.tb02241.x

${ }^{5}$ R. C. Liebermann, I. Jackson, A. Ringwood, Elasticity and phase equilibria of spinel disproportionation reactions, Geophys. J. Int., 50 (1977) 3, 553-586, doi:10.1111/j.1365-246X.1977.tb01335.x

${ }^{6}$ R. M. Hazen, H. Yang, Effects of cation substitution and order-disorder on P-V-T equations of state of cubic spinels, American Mineralogist, 84 (1999), 1956-1960

${ }^{7}$ J. Podwórny, Order-disorder phase transformation in 2:3 spinels, Ceramika - Ceramics, vol. 117, Polish Ceramic Society, Kraków 2014 (in Polish)

${ }^{8}$ F. Martignago, A. Dal Negro, S. Carbonin, How $\mathrm{Cr}^{3+}$ and $\mathrm{Fe}^{3+}$ affect $\mathrm{Mg}-\mathrm{Al}$ order-disorder transformations at high temperature in natural spinels, Physics and Chemistry of Minerals, 3 (2003), 401-408, doi:10.1007/s00269-003-0336-0

${ }^{9}$ J. Podwórny, J. Wojsa, T. Wala, Variation of Poisson's ratio of refractory materials with thermal shocks, Ceramics International, 37 (2011), 2221-2227, doi:10.1016/j.ceramint.2011.03.070

${ }^{10}$ R. Lakes, Deformation mechanism in negative Poisson's ratio materials: structural aspects, Journal of Materials Science, 26 (1991) 9, 2287-2292, doi:10.1007/BF01130170

${ }^{11}$ R. Lakes, Foam structures with a negative Poisson's ratio, Science, 235 (1987) 4792, 1038-1040, doi:10.1126/science.235.4792.1038 